\title{
THE EFFECTS OF STORAGE OF CORNEAL TISSUE ON LANGERHANS CELLS
}

\author{
W. J. ARMITAGE \\ Bristol
}

Since immunological rejection remains one of the main causes of corneal graft failure in humans, the possibility that the risk of rejection may be modulated by the method of corneal storage could have significant consequences for corneal graft outcome. The prospect of such a link between storage and immunogenicity stems from the assertion that donor antigen presenting cells (APC), such as corneal Langerhans cells, play a central role in the rejection of transplanted tissues. ${ }^{1}$ It follows from this that selective destruction of APC in tissues prior to transplantation would reduce the likelihood of stimulating recipient $\mathrm{T}$-cell responses via the direct pathway and thus enhance graft survival.

Whether immunomodulation through such means is relevant to corneal transplantation depends on two main questions. First, is the fate of Langerhans cells during corneal storage influenced by the actual method of storage? Second, to what extent are Langerhans cells involved in stimulating rejection of human corneal allografts?

\section{LANGERHANS CELLS IN CORNEA}

Corneal Langerhans cells are typically, although not exclusively, confined to the peripheral one-third of the epithelium. Their density in epithelium is only $15-20$ cells $/ \mathrm{mm}^{2}$, which is considerably lower than the $250-300$ cells $/ \mathrm{mm}^{2}$ found in conjunctiva or the 500 cells $/ \mathrm{mm}^{2}$ in skin. ${ }^{2}$ Although Langerhans cells are normally found only rarely in the central corneal epithelium, stimulation by chemicals, disease, inflammation and trauma can cause dramatic increases in numbers of Langerhans cells and their migration into the central region. ${ }^{3-5}$

Langerhans cells can be identified in corneal epithelium by their characteristic dendritic form when stained for ATPase. They also express class II MHC antigen but, unlike Langerhans cells in skin

Correspondence to: $\mathrm{Dr}$ W. J. Armitage, Department of Ophthamology, Bristol Eye Hospital, Lower Maudlin Street, Bristol BS1 2LX, UK. epidermis, they appear to lack thymocyte antigen (T6). ${ }^{6}$ While corneal epithelium, endothelium and stromal keratocytes all express class I MHC antigen, the only cells in cornea normally expressing class II MHC antigen are the Langerhans cells in the epithelium and a few dendritic cells scattered throughout the stroma. ${ }^{7}$

\section{EFFECTS OF TISSUE STORAGE ON LANGERHANS CELLS}

Techniques such as irradiation with ultraviolet light, ${ }^{8}$ short-term organ culture ${ }^{9}$ and hyperbaric oxygen ${ }^{10}$ have all been applied to various tissues in attempts to modulate their immunogenicity. There is also evidence from experiments with tissues such as thyroid, skin and pancreatic islets that suggests that manipulation of storage conditions, in particular during cryopreservation, can achieve the twofold aim of retaining tissue viability yet selectively incapacitating APC. ${ }^{11}$

\section{Immunomodulation of Tissues by Freezing}

Survival of cells following freezing and thawing depends on a number of variables, including the rates of cooling and warming, and the type and concentration of cryoprotectant (such as glycerol or dimethyl sulphoxide) used to protect the cells against freezing injury. ${ }^{12}$ For a given set of conditions, cell survival can vary markedly depending on the cell type. It should be possible, therefore, to choose conditions of freezing and thawing that are fatal for one cell type while favouring the survival of others. ${ }^{13}$

The idea of adjusting freezing conditions to achieve immunomodulation of tissues through selective destruction of APC has been pursued by Taylor and colleagues in their studies on pancreatic islet cryopreservation. ${ }^{11,14-16}$ The capacity of beta-cells in frozen and thawed pancreatic islets to secrete insulin is, with appropriate adjustments in cryoprotectant concentration and exposure times, relatively insensitive to cooling rate: islets remain functional after 
cooling over a range of rates from $<1{ }^{\circ} \mathrm{C} / \mathrm{min}$ to $>70{ }^{\circ} \mathrm{C} / \mathrm{min} .{ }^{17,18}$ In contrast, Taylor et al. ${ }^{15}$ found a strong dependence of survival of leucocyte preparations enriched with dendritic cells on cooling rate: while maximal survival of dendritic cells was attained at cooling rates of the order of $1{ }^{\circ} \mathrm{C} / \mathrm{min}$, survival fell sharply at higher cooling rates and was negligible at $70^{\circ} \mathrm{C} / \mathrm{min}$. This suggested that pancreatic islets could be cooled under conditions that would allow survival of the beta-cells yet would kill dendritic cells. When tested by transplantation, this method did indeed extend graft survival: but, in order for the islets to survive high cooling rates, they had to be placed into tissue culture both before and after freezing. ${ }^{18}$ The immunomodulatory effect of freezing was, therefore, confounded by the period in culture, which had previously been shown to be effective by itself in prolonging graft survival in both pancreatic islets and thyroid tissue. ${ }^{9,19}$

Ingham et $\mathrm{al}^{20}{ }^{20}$ investigated the use of freezing to achieve immunodulation of skin. The immunogenecity of skin was assessed by the immunostimulatory capacity of isolated epidermal cells in primary oneway epidermal cell/lymphocyte reaction tests. Metabolically active Langerhans cells must be present in the epidermal cell suspension for a response to be elicited. Ingham et al. found that skin cooled at $30^{\circ} \mathrm{C} / \mathrm{min}$ in $15 \%$ dimethyl sulphoxide retained significant viability while reducing immunogenicity, presumably through incapacitation of Langerhans cells. After freezing, there was little apparent fall in Langerhans cell numbers (detected by $\beta$-glucuronidase staining) in epidermal sheets; but there was no indication that they were metabolically active, and epidermal cell fractions isolated from frozen skin contained far fewer Langerhans cells than cell fractions from unfrozen skin. It was concluded, therefore, that by choosing appropriate freezing conditions both preservation of skin and reduction in immunogenicity could indeed be achieved. Such results with skin, along with those with pancreatic islets and thyroid tissue, thus encouraged the view that immunomodulation through removal of dendritic cells was indeed possible and desirable as a means to facilitate prolonged graft survival.

\section{Storage of Corneas for Transplantation}

There are three main approaches to storage of corneas for transplantation, viz. organ culture at approximately normothermia, hypothermic storage at $0-4{ }^{\circ} \mathrm{C}$, and cryopreservation. ${ }^{21}$ The latter should provide a virtually unlimited storage time, but current methods are too unreliable to be applied successfully by eye banks. Storage at $4^{\circ} \mathrm{C}$ is technically straightforward and is currently the method of choice in the United States, but even with the latest preservation media storage times are limited to less than 2 weeks and many eye banks will not store corneas at $4{ }^{\circ} \mathrm{C}$ beyond 7-10 days. Organ culture, on the other hand, allows up to 4 weeks of storage. This method is used widely among the major European eye banks, and has been used in the Corneal Transplant Service (CTS) Eye Bank in Bristol since 1986.

In Bristol, corneas are stored at $34^{\circ} \mathrm{C}$ in Eagle's minimum essential medium (MEM) with Hepes buffer containing $2 \%$ fetal calf serum, L-glutamine, $25 \mathrm{mmol} / \mathrm{l}$ sodium bicarbonate and antibiotics. Two days before transplantation, the corneal endothelium is examined for any defects by light microscopy and endothelial cell density is estimated. ${ }^{21}$ In the 8 years since it opened, the Bristol eye bank has supplied corneas for more than 11000 grafts in 200 hospitals throughout the United Kingdom and graft survival is $89 \%$ at 1 year.

\section{Effects of Organ Culture on Corneal Langerhans Cells}

The effect of culture on the immunogenicity of thyroid tissue and pancreatic islets has already been mentioned. Holland $e t a l .{ }^{22}$ showed that after more than 1 week in organ culture, Langerhans cells could not be detected by ATPase staining on most human corneas. Loss of Langerhans cells during organ culture has also been reported by Pels et al. ${ }^{23}$ The corneal epithelium comprises five or six layers of cells, but epithelium is shed during organ culture, leaving only two or three layers of cells. The loss of Langerhans cells is thought to be mainly a consequence of these epithelial changes.

\section{Does Organ Culture Reduce Corneal Immunogeni- city?}

Despite the apparent absence of Langerhans cells in organ-cultured corneas and the reduced amount of epithelium, immunological rejection is still the most common cause of graft failure. According to the Corneal Transplant Follow-Up Study (CTFS), ${ }^{24}$ which monitored the outcome of 2311 grafts in the United Kingdom, the overall graft survival rate at 1 year was $89 \%$, and rejection-free survival was $87 \%$. Of the 207 grafts that failed, 69 (33\%) were the result of immunological rejection. The great majority of grafts in the CTFS used organ-cultured corneas, but the $8 \%$ of grafts carried out with corneas stored for short periods at $4{ }^{\circ} \mathrm{C}$ (either as whole eyes or in M-K medium) were not associated with an increased risk of failure or rejection. Increased risk of rejection was associated with vascularisation of the recipient cornea and previously failed grafts. A direct comparison of grafts using corneas stored at $4{ }^{\circ} \mathrm{C}$ or by organ culture also failed to show any differences in rejection rates. ${ }^{25}$

The supposition that organ culture reduces 
immunogenicity of human corneas through loss of Langerhans cells appears, therefore, to be somewhat tenuous - perhaps purely because a central $7.5 \mathrm{~mm}$ corneal button is unlikely to possess many Langerhans cells even in a 'fresh', unstored cornea.

\section{CORNEAL LANGERHANS CELLS AND GRAFT REJECTION}

Given their low numbers and typical absence from the central cornea, the extent to which donor Langerhans cells act as professional antigen presenting cells (APC) in stimulating allograft rejection responses in human corneal transplantation has yet to be resolved.

Chemical stimulation with dinitrofluorobenzene (DNFB) was used by Rubsamen et $_{\text {al }}{ }^{26}$ to increase numbers of Langerhans cells in murine corneas before heterotopic transplantation. Donor corneas that contained high numbers of Langerhans cells were capable of sensitising recipients and subsequent skin grafts were rejected much more rapidly than in recipients that had received corneal grafts without Langerhans cells.

On the other hand, Gebhardt ${ }^{27}$ questioned whether an orthotopic corneal graft carried sufficient APC to stimulate a host response. Class II positive cells derived from rat donor spleens were injected into either corneal stroma or the peritoneal cavity of recipient rats. Subsequent skin grafts in the latter group were rejected more rapidly, whereas injection of even $2 \times 10^{7}$ class II bearing cells into stroma failed to elicit an accelerated rejection response.

$\mathrm{Katami}^{28}$ studied corneal rejection phenomena in rats in an extensive series of experiments. Evidence that Langerhans cells could play an important role came from the following observations. First, grafts larger than $3 \mathrm{~mm}$ in diameter were rejected whereas grafts less than $2 \mathrm{~mm}$ in diameter were not. Second, grafts with few Langerhans cells (taken from the centre of a donor's cornea) but grafted to a recipient's peripheral cornea tended to show chronic rejection; but grafts with many Langerhans cells (from a donor's peripheral cornea) grafted to a recipient's central cornea tended to be acutely rejected. Finally, purported depletion of APC by hypothermic storage for 1 week or by UV-B irradiation prevented acute rejection. .

Removal of donor epithelium from human corneas has been suggested as a way of lowering the risk of graft rejection either by reducing the overall antigenic load (the epithelium comprises $90 \%$ of the cells in a cornea) or, more specifically, by removing the donor Langerhans cells. A prospective, randomised study showed that patients who received corneas devoid of donor epithelium had a far lower incidence of rejection than those who were grafted with corneas with an intact epithelium ( $8 \%$ vs $30 \%) .{ }^{29}$

Reports that smaller corneal grafts in humans survived better than larger grafts have been put forward as evidence for involvement of Langerhans cells in allograft rejection. ${ }^{30}$ Multifactorial studies that simultaneously analysed donor, operative and recipient factors could not confirm such a clear-cut effect of graft size, ${ }^{31}$ or found that grafts both smaller than $7 \mathrm{~mm}$ or larger than $8 \mathrm{~mm}$ showed poorer survival. ${ }^{32}$

\section{What is the Mechanism of Human Corneal Allograft Rejection?}

Grafts in rats or mice can be manipulated such that the donor button can contain various numbers of Langerhans cells. It appears from such studies that acute rejection is associated with the presence in the graft of donor Langerhans cells and that strategies to reduce or eliminate donor Langerhans cells prolong graft survival. The evidence for such a relationship in human corneal grafts is circumstantial. In the first place, it is unlikely that human corneal buttons carry many donor Langerhans cells because of the restricted distribution of these cells to the periphery of the cornea. Although complete removal of the epithelium appears to reduce the incidence of rejection episodes, it is not necessarily the case that large grafts are more susceptible to failure than small grafts. Moreover, organ culture of human corneas not only removes Langerhans cells but also reduces the amount of epithelium, yet there is no firm evidence of reduced risk of rejection when such corneas are transplanted.

There would appear to be three options for inducing an allograft reaction in the presumed absence of donor Langerhans cells: first, that donor stromal dendritic cells act as APC; second, that donor epithelial or endothelial cells act as APC; and, finally, that host APC activate recipient T-cell responses via the indirect pathway. All cell types in the human cornea express class I MHC antigen, but class II antigen is normally expressed only by the Langerhans cells and by a few dendritic cells in the stroma. ${ }^{7}$ Unfortunately, little seems to be known of the fate of the stromal dendritic cells either during storage or following transplantation. As far as antigen presentation by other corneal cells is concerned, it has been shown in a number of studies that corneal epithelium, endothelium and stromal keratocytes can express class II antigen when stimulated in vitro with gamma-interferon and in vivo during allograft rejection episodes. ${ }^{33-35}$ But expression of class II antigen per se is insufficient for T-cell activation, which also requires the presence of co-stimulatory factors such as interleukin-1 (IL-1). Indeed, the absence of such factors could result in 
down-regulation of the T-cell response. ${ }^{36}$ IL-1 production by corneal epithelium and endothelium has, however, been reported. ${ }^{37}$ In addition, corneal endothelium induced to express class II antigen can function as stimulator cells in a mixed leucocyte reaction, ${ }^{38}$ and presentation of viral antigen by corneal epithelium in the absence of Langerhans cells has also been postulated. ${ }^{39}$

If donor APC are either absent or present in insufficient numbers to stimulate host T-cell responses, then it is possible that host Langerhans cells could initiate an allograft rejection response via the indirect pathway. Pepose et al..$^{35}$ found Langerhans cells in the central region of rejecting corneas, and they concluded that these cells were of host, not donor, origin because of their failure to detect class II positive cells in the centre of control corneas. There is some, albeit preliminary, evidence to support the indirect pathway of T-cell activation in corneal transplantation from the results of class II MHC matching in the Corneal Transplant Follow-Up Study. ${ }^{24}$ Class II matching should reduce the likelihood of T-cell activation via the direct pathway, whereas the indirect pathway should be unaffected or even enhanced by class II matching. ${ }^{40}$ The CTFS data showed a beneficial effect of class I matching but increased risk of rejection with class II matching. Confirmation of this finding would, therefore, lend support to the contention that recipient APC may be involved in the activation of allogeneic T-cell responses in corneal transplantation.

In summary, Langerhans cells are lost from corneas during storage by organ culture; but, unlike other tissues such as thyroid, skin and pancreatic islets, this depletion of APC does not appear to reduce the likelihood of graft rejection, at least in humans. Corneal grafts in rodents, where the population of Langerhans cells can be artificially elevated in the donor cornea before grafting, have shown that donor Langerhans cells can play a role in initiating allograft rejection of cornea. On the other hand, the typical scarcity of Langerhans cells in the central cornea suggests that human corneal grafts are likely, especially following storage by organ culture, to carry few, if any, Langerhans cells. The extent to which donor Langerhans cells are involved in rejection of human corneas is, therefore, open to question.

Key words: Allograft rejection, Corneal storage, Langerhans cells, Organ culture.

\section{REFERENCES}

1. Lafferty KJ. Immunogenicity of foreign tissues. Transplantation 1980;29:179-83.

2. Rodrigues MM, Rowden G, Hackett J, Bakos I. Langerhans cells in the normal conjunctiva and peripheral cornea of selected species. Invest Ophthalmol Vis Sci 1981;21:759-65.
3. Niederkorn JY, Peeler JS, Mellon J. Phagocytosis of particulate antigens by corneal epithelial cells stimulates interleukin-1 secretion and migration of Langerhans cells into the cornea. Regional Immunol 1989;2:83-90.

4. Lang RM, Friedlander MH, Schoenrock BJ. A new morphologic manifestation of Langerhans cells in guinea pig corneal transplants. Curr Eye Res 1981;1:161-7.

5. Brown J, Soderstrom CW, Winkelmann KK. Langerhans cells in guinea-pig cornea: response to chemical injury. Invest Ophthalmol 1968;7:668-71.

6. Seto SK, Gillette TE, Chandler JW. HLA-DR ${ }^{+} / \mathrm{T}^{-}$ Langerhans cells of the human cornea. Invest Ophthalmol Vis Sci 1987;28:1719-22.

7. McCallum RM, Cobo LM, Haynes BF. Analysis of corneal and conjunctival microenvironments using monoclonal antibodies. Invest Ophthalmol Vis Sci 1993;34:1793-803.

8. Lau H, Reemtsma K, Hardy MA. Prolongation of rat allograft survival by direct ultraviolet irradiation of the graft. Science 1984;223:607-9.

9. Lafferty KJ, Cooley MA, Woolnough J, Walker KZ. Thyroid allograft immunogenicity is reduced after a period in organ culture. Science 1975;188:259-61.

10. Talmage DW, Dart GA. Effect of oxygen pressure during culture on survival of mouse thyroid allografts. Science 1978;200:1066-7.

11. Pegg DE, Taylor MJ. Immunological modification of grafts during storage. In: Calne RY, editor. Transplantation immunology: clinical and experimental. London: Oxford University Press, 1984:391-409.

12. Mazur P. Cryobiology: the freezing of biological systems. Science 1970;168:939-49.

13. Knight SC, Farrant J, Morris GJ. Separation of populations of human lymphocytes by freezing and thawing. Nature 1972;239:88-9.

14. Taylor MJ, Bank HL. Function of lymphocytes and macrophages after cryopreservation by procedures for pancreatic islets: potential for reducing tissue immunogenicity. Cryobiology 1988;25:1-17.

15. Taylor MJ, London NJM, Thirdborough SM, Lake SP, James RFL. The cryobiology of rat and human dendritic cells: preservation and destruction of membrane integrity of freezing. Cryobiology 1990;27: 269-78.

16. Taylor MJ, Foreman J, Biwata Y, Tsukikawa S. Prolongation of islet allograft survival is facilitated by storage conditions using cryopreservation involving fast cooling and/or tissue culture. Transplantation Proc 1992;24:2860- 2 .

17. Rajotte RV, Warnock GL, Bruch LC, Procyshyn AW. Transplantation of cryopreserved and fresh rat islets and canine pancreatic fragments: comparison of cryopreservation protocols. Cryobiology 1983;20: 169-84.

18. Bank HL, Davies RF, Emerson D. Cryogenic preservation of isolated rat islets of Langerhans: effect of cooling and warming rates. Diabetologica 1979; 16:195-9.

19. Kedinger M, Haffen K, Grenier J, Eloy R. In vitro culture reduces immunogenicity of pancreatic endocrine islets. Nature 1977;270:736-8.

20. Ingham E, Matthews JB, Kearney JN, Gowland G. The effects of variation of cryopreservation protocols on the immunogenicity of allogeneic skin grafts. Cryobiology 1993;30:443-58.

21. Armitage WJ, Moss SJ. Storage of corneas for 
transplantation. In: Easty DL, editor. Current ophthalmic surgery. London: Baillière Tindall, 1990:193-9.

22. Holland EJ, DeRuyter, Doughman DJ. Langerhans cells in organ-cultured corneas. Arch Ophthalmol 1987; 105:542-5.

23. Pels E, van der Grag R. HLA-A, B, C and HLA-DR antigens and dendritic cells in fresh and organ culture preserved corneas. Cornea 1985;3:231-9.

24. Vail A, Gore SM, Bradley BA, Easty DL, Rogers CA, Armitage WJ. Influence of donor and histocompatibility factors on corneal graft outcome. Transplantation, 1994;58:1210-17.

25. Moll AC, van Rij G, Beekhuis WH, Reneradel de Lavalette JHC, Hermans J, Pels E, Rinkel-van Driel E. Effect of donor cornea preservation in tissue culture and in McCarey-Kaufman medium on corneal graft rejection and visual acuity. Doc Ophthalmol 1991; 78:273-8.

26. Rubsamen PE, McCulley J, Bergstresser PR, Streilein $\mathrm{JW}$. On the Ia immunogenicity of mouse corneal allografts infiltrated with Langerhans cells. Invest Ophthalmol Vis Sci 1984;25:513-8.

27. Gebhardt BM. The role of class II antigen-expressing cells in corneal allograft immunity. Invest Ophthalmol Vis Sci 1990;31:2254-60.

28. Katami M. The extent of immunological privilege of orthotopic corneal grafts in the rat. PhD thesis, University of Cambridge, 1990.

29. Tuberville AW, Foster CS, Wood TO. The effect of donor cornea epithelium removal on the incidence of allograft rejection reactions. Ophthalmology 1983; 90:1351-6.

30. Völker-Dieben HJ, D'Amaro J, Kok-van Alphen CC. Hierarchy of prognostic factors for corneal allograft survival. Aust NZ J Ophthalmol 1987;15:11-8.

31. Sanfilippo F, Foulks GN. The role of histocompatibility in human corneal transplantation. Transplantation Proc 1989;21:3127-9.

32. Williams KA, Roder D, Esterman A, Muehlberg SM, Coster DJ. Factors predictive of corneal graft survival. Ophthalmology 1992;99:403-14.

33. Young E, Stark WJ, Prendergast RA. Immunology of corneal allograft rejection: HLA-DR antigens on human corneal cells. Invest Ophthalmol Vis Sci 1985;26:571-4.

34. Donnelly JJ, Orlin SE, Wei Z-G, Raber IM, Rockey $\mathrm{JH}$. Class II alloantigen induced on corneal endothelium: role in corneal allograft rejection. Invest Ophthalmol Vis Sci 1990;31:1315-20.

35. Pepose JS, Gardner KM, Nestor MS, Foos RY, Pettit TH. Detection of HLA class I and II antigens in rejected human corneal allografts. Ophthalmology 1985;92:1480-4.

36. Markmann J, Lo D, Naji A, Palmiters RD, Brinster RL, Heber-Katz E. Antigen presentation by class II expressing pancreatic beta cells. Nature 1988; 336:476-9.

37. Weng J, Wilson SE, Schultz GS, Chegini N, He Y-G. EGF, TGF alpha, TGF beta, acidic FGF, basic FGF, and IL-1 proteins in the cornea. Invest Ophthalmic Vis Sci 1994;35:1941.

38. Donnelly JJ, Li W, Rockey JH, Prendergast RA. Induction of class II (Ia) alloantigen expression on corneal endothelium in vivo and in vitro. Invest Ophthalmol Vis Sci 1985;26:575-80.

39. Fahy GT. Alterations in Langerhans cells in the cornea during herpes simplex keratitis. PhD thesis, University of Bristol, 1991.

40. Lechler RI, Batchelor JR. Restoration of immunogenicity to passenger cell-depleted kidney allografts by the addition of donor strain dendritic cells. J Exp Med 1982;155:31-41. 